\title{
University Library Directors in the Association of Research Libraries: The Next Generation, Part One
}

\section{Peter Hernon, Ronald R. Powell, and Arthur P. Young}

\begin{abstract}
Using multiple means of data collection, this study identifies the attributes that present and future directors of the academic libraries in the Association of Research Libraries need to possess. Present-day directors must possess a wide variety of attributes and are less likely to remain in the same position for as many years as their predecessors did. With the aging population of academic librarians, matching the right individual with the right institution is likely to be increasingly difficult in the future.
\end{abstract}

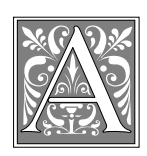

t different points in time, various studies of university library directors within the Association of Research Libraries (ARL) have reported on gender, age, highest degree obtained, personality type, average salary, progression path to reach the position, length of time in the position, and reasons for leaving the position. ${ }^{1}$ For instance, studies have shown that:

In 1994, more than 82 percent [of the ARL directors] were between the ages of 45 and 69 . While the comparable figure from 1990 is almost identical, the age profiles for the 2 years are quite different. The aging trend that affected the ARL population between 1990 and 1994 apparently affected the director group as well, since the percentage of the population aged 55 and over rose from 25.5 to 43 percent. The percentage of the population in the 60-64 age group is twice that of the population as a whole, but this is not surprising given the experience generally required of directors. However, directors are not more inclined than other ARL librarians to remain in their positions after age $65 .^{2}$

Authors have characterized the directorship as a "position in transition" ${ }^{3}$ because directors move from being internal managers to being institutional leaders who exhibit "creativity, risk taking, innovation, and intuition." ${ }^{4}$ In their classic 1973 College $\mathcal{E}$ Research Libraries article, Arthur M. McAnally and Robert B. Downs reported that "all was not well in the library directors' world." The fact that seven positions opened in one year (1971-1972), they thought, reflected a "vague feeling of uneasiness" with academic librarianship and higher educa-

Peter Hernon is a Professor in the Graduate School of Library and Information Science at Simmons College; e-mail: peter.hernon@simmons.edu. Ronald R. Powell is a Professor in the Library and Information Science Program at Wayne State University; e-mail: ad5328@wayne.edu. Arthur P. Young is the Dean of University Libraries at Northern Illinois University; e-mail: ayoung@niu.edu. 
tion. After all, "these are major universities on the national scene whose directorships had been stable in the past" (until the 1970s, university directors tended to stay in one position until they retired)..$^{5}$

One way to update their finding is to look at current directors and the years they first became ARL directors. From 1973 through 1979, nine became firsttime directors, four of them in 1979. The next decade reflected more flux: thirtyeight individuals became first-time directors. Figure 1, which is not limited to academic libraries, shows that sixty-nine became directors in the 1990s and that, in just two years (1996 and 1997), twentyeight joined the ranks of ARL directors. The figure excludes those who retired or otherwise left the position of director. Furthermore, some of the current directors later moved to other ARL institutions. In 2000, directors had been secured by three institutions and the position was unfilled in seventeen others as this paper was being written. With university librarians now comprising an older population, the high rate of turnover is likely to continue, especially if more people opt for early retirement. ${ }^{6}$

\section{The purpose of this two-part study is to fill the research void, to probe such issues, and to provide insights for those in education and leader- ship programs who want to prepare and nurture the next generation of directors.}

With the high rate of turnover, the perceived brief period that people stay in these upper-administrative positions, and the continuation of dramatic change in the new millennium, a study is needed to examine where the next generation of directors will come from and what attributes (knowledge, skills, and critical competencies) they will be expected to have. Moreover, such a study should address what attributes the present generation should possess and whether those attributes are likely to change in the near future. The purpose of this two-part study is to fill the research void, to probe such issues, and to provide insights for those in education and leadership programs who want to prepare and nurture the next generation of directors. In addition, the findings of this study may be useful to search committees trying to fill positions, to directors mentoring senior staff, and to those individuals aspiring to become directors of ARL libraries.

\section{Present-day Directors}

Sixty-nine individuals became directors of ARL academic libraries between 1994 and the end of the decade. (Note that figure 1 examines a different issue: the year in which current directors first became ARL directors.) Each one had assorted administrative experience showing a progression of responsibility. Prior to assuming the directorship, they came from (in descending order of occurrence):

- ARL libraries (assistant or associate directors, perhaps as internal hires);

- ARL libraries (directors moving to more prestigious institutions); and

- non-ARL libraries (directors of college or university libraries).

In one instance, the individual came from the teaching faculty.

Despite the amount of change in the position of director, the mean number of years of experience in their current position was 11.07 in $1994(\mathrm{n}=94)$ and 11.43 in $1998(n=96)$. Given the high turnover rate and the fact that some directors worked in the same library before assuming their present position, the mean only serves as a very general indicator. Another general indicator is the length of time that the directors have been in librarianship. In this case, the mean number of years was 26.58 in $1994(n=104)$ and 28.46 in $1998(\mathrm{n}=110) .{ }^{8}$

Figure 2 addresses an issue that was on the minds of a number of assistant/ associate/deputy directors interviewed during the course of this study: How essential is it for a director to have a doctorate-Ph.D. or other? It would seem that search committees raise the same question. Figure 2 provides some trend 


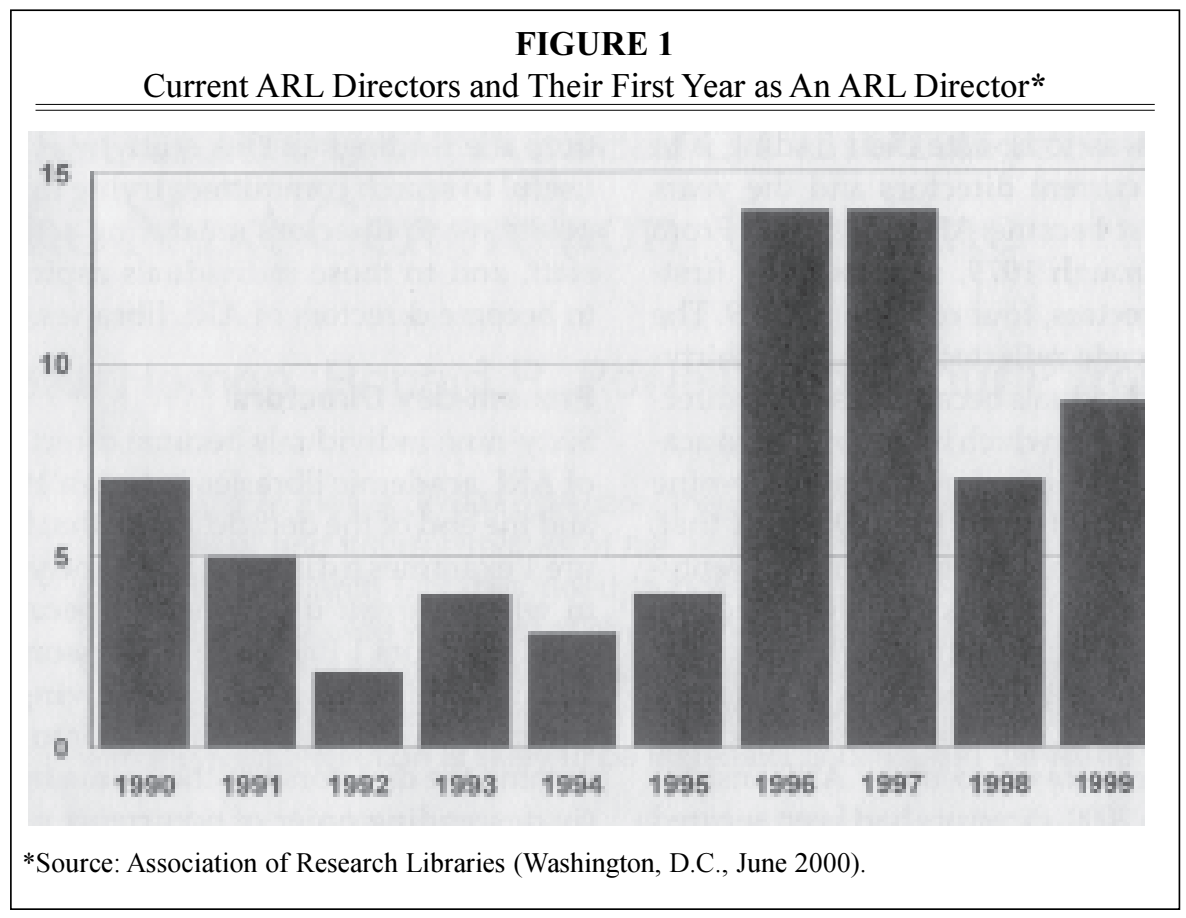

data on university library directors in ARL. Clearly, not all directors responded to the ARL-conducted surveys (19851998). Furthermore, the number of ARL libraries has increased over time. For the 1998 survey, the response rate was 81.1 percent. Those with a doctorate received it in disciplines such as library and information science (LIS), history, public administration, and education. Regarding the 1998 survey, four directors did not have a degree in LIS: one had a master's degree and three had a Ph.D.

\section{Review of the Literature}

Terrence F. Mech, in a study of 354 academic library directors, found that they tend to be more involved with internal, rather than external, managerial roles. ${ }^{9}$ Michael Ann Moskowitz, in a study conducted in the 1980s, reached a similar finding, but both investigators found some differences by type of institution. ${ }^{10}$ Each speculated about why these differences occurred. Mech also discovered that library directors, like other academic managers, tend to be reactive. ${ }^{11}$ Keith $\mathrm{M}$.
Cottam documented the shift in roles, functions, and activities "from predominantly internal affairs to an increasing emphasis on external ones." 12 Susan K. Martin noted that "with increased costs and decreased funding," university librarians are now very actively involved in a particular external role-donor relations. ${ }^{13}$

Dana C. Rooks observed that "the position of director of a major research library is indeed becoming more demanding," but that "the job ... is still manageable." ${ }^{14}$ She found that the director must display "three major qualities":

- flexibility, adaptability, and a willingness to accept change as a way of life;

- a stable and equitable temperament and the ability to maintain an emotional balance under constant tensions; and

- endurance. $^{15}$

In an internal report, Peter Hernon and Carolynne Presser identified fifteen characteristics that a new director must possess. A new director must:

- have a vision and be able to work with others to achieve it; 
- be a leader who is able to motivate staff;

- be knowledgeable about scholarly communication and appreciate the role and value of scholarship;

- have demonstrated experience in planning with key stakeholders and setting realistic priorities;

- have good communication skills and be able to work effectively within the library system, the university, and the larger community;

- be an advocate of the library;

- be knowledgeable about technological applications in libraries, issues and trends in higher education, and the movement toward multidisciplinarity;

- be knowledgeable about, and have experience with, human resources management;

- be committed to resource sharing and express a willingness to explore opportunities for partnerships and to work cooperatively with other libraries;

- be supportive of staff development;

- be able to put together a management team and a management structure for the library;
- be able to empower the management team and delegate responsibility, where appropriate-be a team player;

- be open-minded and approachable, and embrace change;

- have a public service focus, meaning that services to the community will be the driving force behind the decisions taken; and

- recognize that external funding is important and be willing to work with the university's development office in fund-raising. ${ }^{16}$

Some of the above-mentioned characteristics relate to the director's internal role and others relate to an external role. Both roles require leadership. As Mech noted, "although leadership may be defined in many ways, we all tend to recognize it when we see it. Leadership may be more of a relationship between people than a personal characteristic." ${ }^{17}$ Richard T. Sweeney discussed leadership, the qualities a leader demonstrates, the roles leaders assume, and leadership strategies. $^{18}$

Ruth J. Person and George C. Newman, in a study of the selection pro-

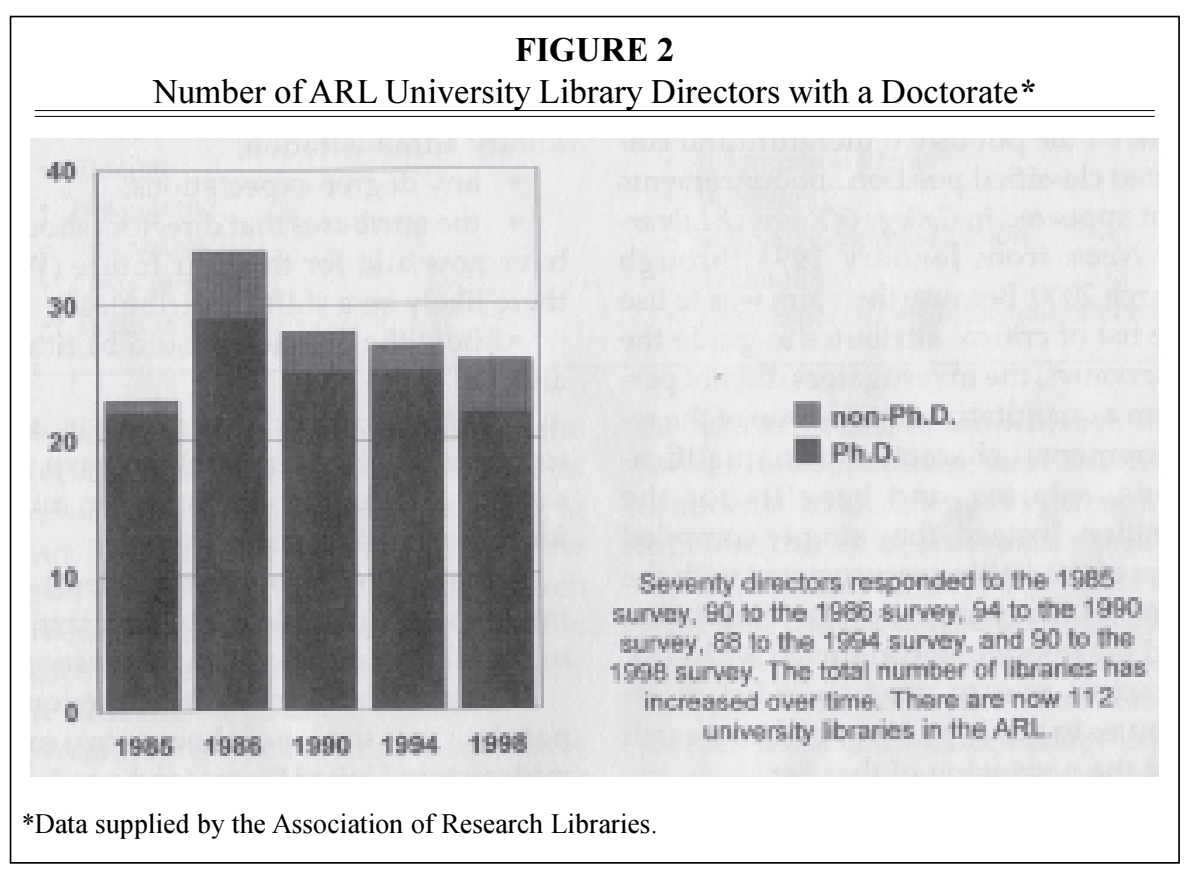


cess for the university librarian at five universities, identified the common characteristics of successful searches as, for instance, a commitment to the library by the higher administration and an interest in the outcome of the search by the librarians, faculty, and administration. ${ }^{19}$ Their work, based on interviews with key participants in the process, complements this study and merits replication.

Ronald R. Powell conducted surveys in which respondents were asked to rate attributes for academic librarians and explore the baseline of professional knowledge they need. ${ }^{20}$ The purpose of such research was to provide feedback to library education, whereas this study addresses those institutions seeking directors and those individuals interested in obtaining such positions. Powell's work is relevant to the second phase of this study, which is application of the Delphi technique (which is not reported here). That study will provide a schematic representation of the attributes, cluster them as appropriate, and identify those that are most important for new directors to have now and in the near future.

\section{Procedures}

This study involves multiple methods of data collection. First, to develop an initial list of attributes, the investigators reviewed the published literature and collected classified position announcements that appeared in College $\mathcal{E}$ Research Libraries News from January 1994 through March 2000. Because their aim was to use the list of critical attributes to guide the interviews, the investigators did not perform a quantitative comparison of the requirements, characteristics, qualifications, salaries, and benefits for the position. Instead, they simply compiled a list of the attributes associated with the position. The purpose of the compilation and the interviews conducted with ARL directors was to produce a list of attributes to guide part two of the research and the narrowing of that list.

An initial set of interview questions was pretested at two ARL libraries, one with the senior administrative team and the other with the director. ${ }^{21}$ The second pretest, which was conducted by telephone, elicited ten attributes as essential: understanding of campus politics; ability to operate successfully in the campus environment; ability to develop partnerships; ability to compromise; high energy; fund-raising skills; excellent management skills; well organized and focused; ability and willingness to delegate responsibility; and understanding of libraries as complex organizations. As for any changes in the list in the near future, this director identified versatility and the ability to "shift gears" frequently.

The investigators reviewed the process by which they would conduct interviews and standardized the procedures. Based on the comments given during the pretest, some of the interview questions were modified and others were deleted from the list. The final list of questions centered on:

- where the next generation of directors will likely come from;

- whether they must demonstrate a substantive record of successful accomplishment, showing progressive administrative responsibilities related to an academic or research library;

- any preferred length of time for gaining experience at the upper level of library administration;

- any degree expectations;

- the attributes that directors should have now and for the near future (Will there likely be a shift in attributes?);

- how the position should be titled; and

- whether presidents, provosts, and search committees are likely to have the same or difference expectations in mind for the successful candidate.

Although these questions guided each interview, the interviewer had discretion to ask additional (but related) questions.

Directors at fifteen libraries, predominately in the northeastern and midwestern United States (and one from Canada) were interviewed between November 1999 and July 2000. Each library 


\section{FIGURE 3}

Attributes Mentioned in Classified Job Advertisements

\section{Leadership}

- Direct: implement and delegate (management team/structure)

- Manage personnel

- Manage/shape change

- Motivate: empower management team, promote professional growth of staff

- Support diversity (people and collections)

\section{Plan}

- Fiscal management and resource allocation: access versus ownership, balance electronic resources and print collections, consortia and networks, partnerships, resource sharing

- Priority setting

- Program/service development and integration

- Use and integration of technology

- Vision of library within university

\section{Ability to:}

- Be an advocate

- Collaborate

- Compromise

- Develop (or further) a national reputation/visibility

- Embrace change

- Function in shared decision making and political environment

- Gain grants and be successful in donor relations

\section{Individual Traits}

- Approachable

- Creative

- Flexible

- Imaginative

- Innovative

- Open minded

- Takes initiative

\section{Skills}

- Analytic and problem solving

- Consensus building

- Interpersonal

- Leadership

- Organizational

- Oral/written communication

- Public relations
Areas of Knowledge

- Digital libraries

- Higher education

- Information literacy

- Publishing

- Scholarly communication

- Technology

- User expectations/information needs was selected for its close proximity to the investigators or its location in a city that one of the investigators was planning to visit. This strategy helped to contain the costs of conducting interviews in such diverse locations. It was decided that the lack of a random sample would not skew the ultimate value of the research.

Within one week after each interview was conducted, the investigators shared the written results with the director. The purpose was to ensure the accuracy of the transcript and to see whether, upon further reflection, there were additional comments. In an attempt to gather more input on the list of attributes, the investigators conducted telephone interviews with four directors who serve as chairs of key ARL committees or whom ARL staff said had a perspective that complemented those of the fifteen interviewees. These four individuals were only asked about attributes. Thus, the total number of directors interviewed was nineteen. 


\section{Classified Position Announcements}

Figure 3 identifies attributes compiled from the announcements in College $\mathcal{E} R e-$ search Libraries News as well as from published articles. Some of the advertisements called for the university librarian to be a scholar. For instance, four search committees sought "academic qualifications, scholarship, and professional accomplishments sufficient to be appointed a Full Professor with tenure." 22 The State University of New York-Stony Brook asked for "evidence of professional growth, demonstrated by publications, teaching, consulting, and other professional activities." 23

A few observations about the contents of the announcements are in order. First, most often there was no mention of any preferred length of time for gaining the prerequisite experience at the upper level of library administration, although six institutions specified the minimum number of years (see table 1). Perhaps the fact that one of these institutions (SUNYStony Brook) is unionized has some sig- nificance. In the other instances, a formal job classification system might state that a position at a certain level requires a specified number of years. However, these are mere speculations suggested by some of the directors interviewed.

Second, when a degree requirement was specified, it was most likely an MLS from an ALA-accredited program. An earned doctorate or another advanced degree in a subject discipline might be listed as preferred. Some institutions obviously wanting a broad pool of candidates merely listed "appropriate advanced degree(s)." In three instances, there was no mention of degree requirements; one institution was willing to consider "equivalent experience" as a substitute for a specific degree.

Third, three institutions asked applicants to submit an essay in addition to a statement of interest, a current curriculum vitae, and a list of references. George Washington University requested "a description of your most recent accomplishments in your current position, and a

\section{TABLE 1}

\section{Minimum Number of Years of Administrative Experience}

\begin{tabular}{ll} 
Institution & Minimum Years \\
\hline Cornell University & $\begin{array}{l}\text { A minimum of five years' experience at the director/ } \\
\text { associate/assistant director level in research libraries } \\
\text { is preferred }\end{array}$
\end{tabular}

Colorado State University

George Washington University

SUNY-Stony Brook

Washington State University

Yale University
At least five years of progressively responsible administration in academic or research libraries, including budget and personnel management

A minimum of three years of senior administrative experience in an academic or research library

At least eight years in responsible management positions in academic libraries

Five years of experience in administrative and managerial positions with at least three years of supervisory experience

Five or more years of successful management experience with a major library 
brief statement of your view of the future directions for university libraries in a research-oriented University." Auburn University required "a vision statement for the Auburn libraries based on the information" contained in the advertisement, and Colorado State University wanted "a statement of leadership philosophy and related qualifications."

\section{Several directors commented on the risk of burnout and discussed what they do to be energized (e.g., "I cannot take the job too seriously; I must have a sense of humor").}

Syracuse University was unique in its desire for "the next University Librarian ... [to be] a creative strategist and entrepreneurial leader who can build successful partnerships and make resource allocations to achieve higher vision." At Wayne State University, the dean had the broadest responsibilities as that position oversees the following administrative areas: the library system, a graduate LIS program, the university press, the university's media services, and the Detroit Area Library Network (DALNET). In addition to addressing all these areas, the announcement called for a person of "national and international stature in the library profession," a facilitator "of affirmative action goals," and a promoter "of diversity and multiculturalism." ${ }^{24}$

\section{The Interviews}

To preserve anonymity, the sites, and thus the participants, are indicated as A through S. Directors at sites P through S were interviewed by telephone only about attributes. (For clarity of presentation, this section uses the general designation of director to refer to chief librarians rather than using titles adopted at each institution.)

Several ARL libraries have streamlined operations, made staff cuts, adopted a team approach to managing the library, reorganized and eliminated positions (even at the upper levels of management), and downsized or flat- tened the organization. In some instances, upper-level managers function as managers without portfolios (lacking specific areas of responsibility). To complicate matters, a number of upper-level administrators, according to the director at site $\mathrm{M}$, may be retiring at the time they are needed to assume directorships.

This same director also explained that "ARL libraries are less homogeneous than they once were and will become even less so in the electronic age, especially if the emphasis is on meeting immediate needs rather than on building a research collection." Some of those interviewed commented on differences between current and past directors. In the past, the position was concerned mostly with collections and volume counts. Today, the position focuses on services and collections that are useful and visible but does not neglect print collections at the expense of electronic resources. In the 1970s, as was pointed out, directors came from collection development and technical services, where they learned to deal with budgets and collections. Today, they might well come from public services. Another difference is that past directors settled into the position and stayed in it sometimes as long as twenty years. Today, there is greater fluidity (see figure 1). Furthermore, present-day directors devote their life to a very time-consuming and demanding position. As the directors at sites $B$ and $G$ noted, "This is not a position for someone with small children, who wants to spend a lot of time with them." They also said that the directors they know are all "workaholics." 25

Some of the assistant directors participating in the pretest interviews were not sure they would make a similar commitment and expressed reluctance about considering a directorship due to the time commitment and pressures, tensions, and anxiety associated with the position. Several directors commented on the risk of burnout and discussed what they do to be energized (e.g., "I cannot take the job too seriously; I must have a sense of humor"). They seem to 
thrive on challenges, a changing environment, interactions with a diverse community, and having a highly motivated senior staff. However, none of them expressed a desire to continue in the position past his or her sixty-fifth birthday.

When told that assistant university library directors were popularly viewed as being highly specialized in particular areas, those interviewed at site A found this characterization to be outdated. The senior managers at site A work as a team and learn about activities beyond their immediate area of responsibility. Their areas are not rigidly set, and their job descriptions are not tightly defined. "If something needs to be done and the director assigns it to us, we do it." Each director discussed the importance of having senior administrators who are willing to accept challenges and assume new roles and responsibilities. They discussed the nurturing environment they try to maintain. At the same time, they emphasized the high expectations and workload they place on those holding these positions.

\section{Where the Next Generation of Directors Will Likely Come from}

With one exception, respondents agreed that future directors would likely come from a broad pool of candidates: ARL library staff in assistant, associate, and deputy librarian positions; ARL directors moving to more prestigious institutions; and directors of non-ARL academic libraries (e.g., the larger state and other well-known institutions in the Association of College and Research Libraries [ACRL]). ${ }^{26}$ Two directors (sites $\mathrm{C}$ and N) suggested that a few positions might even be filled by faculty members, especially at those institutions where there is a tradition of doing so; and another director (site M) suspected that "lower-tier ARL directors may come from the information industry." He was concerned that directors coming from lower tiers of ARL libraries would rely more and more on access to electronic resources and less on collection building and the continued al- location of resources for the collection and preservation of paper-based resources essential to their institution's mission. Thus, "the directors of those libraries may not have the optimal credentials for directing the top 25 or so ARL libraries."

According to three directors (sites E, $\mathrm{F}$, and $\mathrm{K}$ ), those in deputy positions within ARL libraries might not be given "many director-level duties." In some instances, a director may not delegate such duties. Thus, it might be preferable to become the director of a smaller, nonARL library early in one's career and then move into an ARL directorship.

The director at site B explained that there are "tiers to ARL" and that some non-ARL libraries have bigger budgets and more staff than some ARL libraries do. The most prestigious institutions might select directors from other ARL libraries, whereas the others might make their selection from a wider pool of candidates. "Some of these non-ARL directors have more influence on their campus than do some ARL directors," and these non-ARL institutions may be dealing with the same issues as ARL institutions. He mentioned that "Ohio University is at the middle ranking. Use it as a benchmark to see where you come into the ARL."

As another director (site K) mentioned,

directors used to operate their libraries; their jobs were to make things run on a daily basis, and that's not what we primarily do anymore. Our jobs are really to secure the financial and political future of the library. Someone having directorship responsibilities at a medium-sized non-ARL library will more probably have the experience set than someone who's been in an operational role within an ARL library.

However, she noted that the person must come from "a fairly comprehensive university, with multiple colleges in its structure; that offers degrees at different 
levels; and that provides a variety of library services to all these people." This person must have managed budgets, secured financial resources, demonstrated an ability to perform campuswide responsibilities, and possess skills and experiences that are transferable. Examples of individuals who came into directorships from non-ARL libraries are Sarah Pritchard, Fred Heath, Rush Miller, and Charles Lowry.

The director at site $C$ saw senior staff in ARL libraries as being familiar with their institution, but not necessarily with other institutions, and some non-ARL directors as being knowledgeable about ARL institutions. A number of ARL directors, she noted, have had both ARL and non-ARL experience. They might have been associate university librarians at ARL institutions, left that position for a non-ARL directorship, and later returned to the ARL as a director.

The director at site E cautioned that, several years ago, it was speculated that new directorships would be filled largely with non-ARL librarians; however, this development never materialized. The tendency, he explained, is to select directors predominantly from the smaller ARL libraries or associate/deputy/assistant directors in ARL libraries. The director at site $\mathrm{O}$ noted that one university brought in an individual with a doctorate in a relevant area and trained that person; however, this has "been very difficult to do."

Several directors noted that they serve as mentors to their senior management team, give them opportunities to learn, and challenge them to mature and be excited about their work and the library profession. To obtain a directorship, a person must be known and actively engaged in networking. Those interested in the position need to attend:

- ARL-sponsored programs (these might be open to people who are not members of the ARL);

- leadership institutes, such as at the University of California, Los Angeles (UCLA), and Harvard and Emory universities, that cover critical issues facing research libraries and offer a networking environment; and

- ARL management training programs. ARL has begun an institute for minority midcareer librarians called the Leadership and Career Development Program, with the specific purpose of helping minorities to be prepared to assume leadership positions in the future. "This program will likely increase the diversity of ARL directors - sort of the way that the CLR [Council on Library Resources] Internship (1970s and 1980s) and other programs have contributed to the increased number of women directors." Those interested in pursuing a directorship also might obtain membership on OCLC's user council.

In summary, leadership institutes are opportunities for the profession to identify good people and assist in nurturing the development of prospective directors. As the director at site J explained, "Leadership institutes are valuable. They help to create bonds with peers and awareness of issues. They can lead to more nominations for jobs, etc. They are a good developmental tool and a good training and testing ground." Another director (site N) added, "I think [that] so much of being able to do the job is thinking you can do it, and therefore, to the extent that institutes heighten your awareness of what you do, how you do it, and how you personally react in certain situations, they're a good thing, and I believe in them." However, the directors at sites $\mathrm{B}$ and $\mathrm{O}$ cautioned that attending institutes is not enough: "We have known people who came back unchanged." The person must take advantage of the opportunity: "learn, gain experience, broaden ... [his or her] knowledge, and network." As the director at site B explained, "get known."

\section{Demonstrating a Substantive Record of Successful Accomplishment, Showing Progressive Administrative Responsibilities}

The most essential items in the background of a future director, according to 
the director at site $\mathrm{C}$, are previous work experience and accomplishments in the profession. These are "more important than networking or attendance at leadership institutes." The work record, those interviewed maintained, should show progressive administrative responsibilities related to an academic or research library, most likely, experiences gained in more than one library. According to the director at site $\mathrm{H}$, that experience should be in "how to run an organization." The director at site I stressed the importance of experience with information technology in a systems unit and managing human resources. And the director at site $\mathrm{M}$ stressed the importance of grant and foundation work, the management of information systems, and fiscal management.

The director must have a rich background of knowledge and experience and be able to deal effectively with issues such as those depicted in figure 4 . There are definitely:

multiple and competing tensions in the academic library world, and, indeed, in the world of higher education in general. Obvious tensions exist. For example, there is the tension between strategic investment in building and collection infrastructures and the need for more collaboration within consortia for purchasing of digital information which will never be owned or need housing. And it is not simply the conventional tug of war such as local versus consortial investment that creates present and future challenges for academic libraries. ${ }^{27}$

The director at site D equated the successive positions that culminate in the ARL directorship as "climbing the food chain." He noted that there is some attrition along the way as some people, for a variety of reasons, decide not to pursue a directorship. Furthermore, he has found that, as director, there is so much to do. Because "it is harder and harder for one person to do all the stuff that needs to be done," sharing the work becomes more essential. Thus, those reporting to the director can gain a variety of experiences, assuming that the administrative structure is not too compartmentalized.

Individuals seeking to become directors of ARL libraries, as the director at site $G$ explained, must be active in the profession and demonstrate that they can do the job at either a reduced level (associate/assistant university librarian or AUL) or a broad level (director of a library). They must seek a variety of experiences in a complex organization, be promoted within their institution, and gain broad knowledge by attending conferences and continuing education programs and by taking courses, not necessarily culminating in being awarded a degree (e.g., take some business courses). She saw the leadership institutes as a minimum requirement for advancement within a library but realized that participants may use them to gain visibility. She stressed the importance of "educating yourself all the time." She does this now by making presentations to outside groups, attending appropriate conferences outside library and information science, and interacting with the wide assortment of key individuals she meets.

The director at site $\mathrm{K}$ emphasized the importance of being able to transfer one's knowledge to a new organizational culture and knowing the differences between public and private institutions, if the person is proposing to move from one kind of organization to another. "A key to success," she explained, "is knowing the kind of organization you've been in before." The director at site L added that directors should be knowledgeable about the type of institution they are joining.

National standing in the professionbroad experience in national organizations and demonstration of intellectual curiosity through writings and presentations - is important, and "one is not likely to be a final candidate" without 


\section{FIGURE 4}

Some of the Key Issues Facing Academic/Research Libraries*

\section{New Roles and Contributions}

As the volume and complexity of information increases, libraries will need to promote innovation and change in order to meet the critical needs faced by the immediate populations that they serve. Issues include:

- Reshaping the purpose of the library to meet the actual and emerging needs found in the university environment

- Work with other academic disciplines to develop library staff potential outside the current mainstream

- Working creatively with other information service providers to engage the issue of competition in a productive way

- Engaging the changing perspective of teaching/learning in higher education; integrating emerging directions in higher education into the purpose and vision of the library

- Improving communications between the library and the university community regarding impact, cost, intellectual property rights, archiving, and use of electronic resources

- Expanding the influence of the library within the university; integrating the purpose and goals of the library with the university's direction

- Developing strong information management competencies within the student populations

- Connecting values of librarianship with the technological environment and assuming the relevance of librarianship into the future

\section{Financial Infrastructure and Funds Development}

Libraries and information services operations continue to experience spiraling cost increases for information in a variety of formats, while budget allocations remain relatively stable. Issues include:

- Financing human resource development and deployment

- Financing the parallel access systems for traditional and digital information resources

- Financing available technological capabilities in demand by an increasingly sophisticated user population

- Building strong donor relations and creating alternative investing opportunities

- Devising new revenue streams that support library operations and development.

- Crafting fiscal mechanisms to ensure effective and equitable deployment of acquisitions budgets

- Deploying practical tools for cost containment and performance enhancement

\section{Human Resources for the Contemporary Environment}

Appropriate staffing is key to the development of an agile organization capable of meeting the needs of $21^{\text {st }}$ century users. Issues include:

- Recruiting and retaining first-rate staff capable of meeting the intellectual and service challenges of tomorrow

- Strengthening the roles of librarians on campus in accessing, interpreting, and deploying information resources

- Training and developing staff to use new technologies in both teaching and service provision to faculty and students

- Creating a culture of quality and active service involvement, including developing ways to meet independent learners on campus/off campus 


\section{FIGURE 4 (CONT.) \\ Some of the Key Issues Facing Academic/Research Libraries*}

\section{Human Resources for the Contemporary Environment (cont.)}

- Developing strategies to deal with inequitable salary levels and ferocious competition for talent in the marketplace

- Rationalizing a staffing plan and developing priorities for new positions

- Recruiting and retaining professionals from underrepresented racial and ethnic groups

- Developing critical negotiating and influencing skills among staff

- Developing staff capacity to innovate and to manage change

\section{Leadership of the Library as a Dynamic and Complex Organization}

As access to information resources becomes more complex and varied, the successful operation of libraries and information services units becomes more challenging requiring sophisticated leadership, planning, and management skills. Issues include:

- Assessing the library's organizational structure to determine appropriateness to performance requirements

- Managing cycles of expansion and retrenchment without losing touch with core values

- Advancing functional/political relationships between the library and other campus units

- Conceiving of new and more adaptive staffing and administrative structures

- Introducing available information technology

- Building a broad-based understanding of changes in scholarly communication among faculty and administrative leadership

- Balancing priorities among traditional and emerging resources

\section{Intellectual Property and Copyright Issues}

New copyright laws and a movement to rethink the ownership and management of intellectual property created within the academy are prompting widespread examination of intellectual property practices and policies. Issues include:

- The potential for loss of access to intellectual property owned and maintained by commercial interests

- Helping faculty to understand their intellectual property rights and copyright privileges

- Maintaining access to intellectual property during a time of commercialization of electronic text and data files

- Understanding the implications of the Digital Millennium Copyright Act for the university

\section{Archiving and Assuring Long-term Access to Electronic Information}

Academic libraries are increasingly providing immediate access to electronic resources but, in many cases, this information is in transitory format and digitally-born frequently leased rather than owned. Issues are:

- Preservation of extant collections, particularly digitally born resources

- Creation of service strategies for continued access to data and collections stored in potentially fragile or obsolescent formats

- Creation of access paths to digitally stored information

- Sustaining collections of distinction through rough digital preservation

*ARL/OCLC Strategic Issues Forum for Academic Library Directors, "Discussion Paper on Key Issues Facing Academic Libraries" (unpublished) (Washington, D.C.: ARL, 1999), 2-6. 
such standing, explained one director (site E). Instead of saying that the candidates must already have such standing, the director at site $\mathrm{M}$ stated that "they must have the ability to earn a national standing." Two directors (sites F and N) were less certain that national standing was so important. As one of them noted, "Some are well regarded among ARL directors without it. Some are well known for their activity on key ARL initiatives, and this may be more effective." The other explained that "Insofar as it gains the respect of the librarians in your library, I guess that's a good thing. Insofar as it does that, I don't think the faculty notice or care, unless you're engaged in some leadership role in their scholarly organizations."

The director at site I agreed that national standing was not necessarily essential. In some instances, he explained, "attention to internal reorganization may be more important." If there was a choice between the two, all the directors considered the ability to manage to be more important than national standing.

\section{Preferred Length of Time for Gaining Experience at the Upper Level of Library Administration}

Because the position presents numerous and complex challenges, a director should have a progressive record of administrative experiences and accomplishments. However, this progression may be "quick." The more prestigious institutions will likely have a good pool of candidates for the directorship, and, as the director at site D noted, they can "buy" those individuals who have reached the apex of the "food chain." Other institutions may have to "reach further down the food chain and select people whom they will have to prepare," at least to some degree. At the more prestigious institutions, the expectation is that the new director is outcome focused, whereas at other institutions he or she may require some "growth." Where growth is essential, the director at site $\mathrm{K}$ suggested that more institutions should look at individuals who have served as interim directors at their institutions but, for whatever reasons, were not selected as directors.

The director at site $C$ felt that a number of people who have more than five years of varied experience are well qualified to assume a directorship; but the director at site B disagreed, saying that there is a shortage of qualified individuals. The director at site $\mathrm{C}$ is grooming one assistant university librarian who has some aspiration for advancement and who would make a "good director." She lets him represent the library at functions when she is unavailable. Moreover, he has been elected to the faculty senate, where people see him in a nonlibrary and political role. She said that future directors will be younger; but the director at site E disagreed, reasoning that given the experiences needed, they will be older.

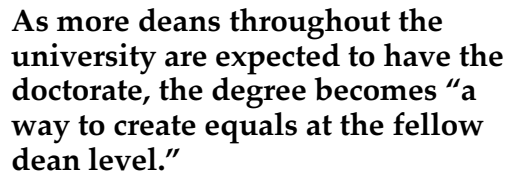

As more deans throughout the university are expected to have the doctorate, the degree becomes "a way to create equals at the fellow dean level."

The director at site $\mathrm{H}$ recommended seven to eight years of experience at the upper level of research library administration but cautioned that the nature and breadth of experience is more important than the length of time: "A person, for example, who has directed only a reference department for a number of years is probably not prepared to direct an ARL library." The director at site I advocated five to seven years of progressive administrative responsibility, but not necessarily within an ARL library. He agreed on the importance of the nature of one's experience.

The director at site $\mathrm{L}$ mentioned the importance of having gone through a budget cycle at least five times and having "lived through a couple of administrations." The director at site J advocated at least ten years of experience. That experience might be gained in a corporate library ("understanding the business 
side and recognizing that a library is not a given"), the private sector (e.g., gaining knowledge of marketing and fundraising), or in a professional association (learning to work with volunteers and to manage people).

\section{Degree Expectations}

According to most of the directors, except for faculty members who might assume a directorship, an MLS from an accredited program is the basic degree requirement. As one director (site B) with a doctorate in a discipline other than LIS explained, "the larger the library, the less important the Ph.D. degree is" because larger libraries look for management and status in the profession much more than they do vitae listing publications. Besides, "any pool limited to those individuals with doctorates and publications would be too restrictive." This person also expressed the same sentiment that any specific degree, other than the MLS, is "preferable." The director at site $\mathrm{H}$ declared that "earning a doctorate does not give a person an understanding of how research is done in all disciplines." He sees his master's degree in business administration (MBA) and his doctorate in history as useful, especially the MBA: "Eighty percent of the decisions I make are affected by my MBA perspective." The breadth of experience for the past decade is more important than a specific degree or being in certain positions for a specific number of years.

The director at site $\mathrm{N}$ wished that he had a doctorate but did not think that the lack of one had impaired his ability to "do my job or how I'm viewed by either the librarians or the faculty. At this institution, a librarian is a librarian, and librarians do what they do, and faculty do what they do. No role confusion, and we're not looked down on, we're respected for what we do. We are a service organization."

One of the directors holding a doctorate (site J) was an advocate of having the doctoral degree, arguing that it provides "more credibility relative to the faculty and to the academic (research and teaching) mission. It helps to create more of a collegial feeling with deans and other faculty." As more deans throughout the university are expected to have the doctorate, the degree becomes "a way to create equals at the fellow dean level."

According to the director at site D, a doctoral degree gives the director "a leg up in establishing cordial relations with the faculty....It gets your foot in the door; the rest is up to the individual." The director at site F suggested that "the Ph.D. is an advantage, other things being equal; however, there are good directors who do not have it." Nonetheless, the degree "may be somewhat less important as more deans' positions are downgraded to directors' positions." The director at site I explained that:

There is less demand for the librarian-scholar and more for the leader administrator and visionary. So, the most important academic training is the MLS and a second master's degree in an appropriate field. The Ph.D. is less necessary. Faculty are more impressed with what the director does than with his/her degrees. Degree requirements need to match the job demands. Directors are spokespersons on a variety of issues so they need to be widely read and advocates for the university's agenda.

The director at site E suspected that the doctorate has not become a universal requirement, as was once expected, in part because it would reduce the size of the pool of candidates too much. Another director (site F) saw a shift from scholarlibrarians in the candidate pool to those who are more business focused. He detected a fundamental change: a shift from the "directors of the 60s and early 70s, some of whom didn't really earn their positions; they wouldn't be successful now." A critical point, he noted, was that expectations of a director have increased, a trend that is likely to continue. 
As the director at site $G$ noted, James M. Matarazzo, dean of the Graduate School of Library and Information Science at Simmons College, has remarked that there will be a serious shortage of librarians by the year 2010, when an estimated 83,866 librarians will reach the age of 65 . To complicate matters, he noted that this number "does not allow any[one] in practice to retire early or leave the field for another reason." $\mathrm{He}$ asked, "Where will the replacements for these projected retirees come from?" 28 Based on those data, the director interviewed projected a shortage of qualified individuals within library and information science to fill the void for ARL libraries. Clearly, universities may have to turn to people outside the profession, specifically to individuals with a master's in business administration and managers of large organizations. At her institution, the administration did not want a "conventional ARL librarian." As academic institutions change and directors assume the role of chief information officer (CIO) or become chief executive officers (CEOs) with wide-ranging responsibilities, the attributes for new directors change and focus more on financial management and entrepreneurship. As she explained, "I manage 350 employees, a \$35 million budget per year (not counting endowment funds), a library, and a university press."

\section{Attributes to Have Now and in the Near Future}

According to the director at site $\mathrm{P}$, the director "functions in a schizophrenic environment," almost as though he or she navigates two opposite poles. Thus, the director is both print collection and digital oriented; a manager and an entrepreneur; and inner (financial manager) and outside focused (entrepreneur). Furthermore, he or she must be agile (able to carry out many assignments simultaneously), comfortable working in an ambiguous university administrative environment; committed to understanding advocacy and being an advocate for major information policy issues at the national and state levels; politically savvy; have public relations skills; and create and take advantage of faculty or academic partnerships in which the library serves faculty and deals with them as research peers (e.g., a digital knowledge center involving faculty and research and development projects with faculty). "The library enjoys the vitality, and the faculty work with the library in new and different ways."

The classified advertisement, one director (site C) explained, "casts the net widely." At the same time, it might be a "wish list" (director at site B) and contain some elements (e.g., years of minimal experience and a degree preference) likely to start the narrowing process. The director at site D maintained that an advertisement uses language that reflects the institution's values and experiences. However, advertisements are less successful in capturing important attributes, such as "zeal" and "energy."

As that same director (site D) explained, "I have never hired a university librarian," but "I believe that the list" (see figure 3) should not be regarded as "scout badges" that a person should gather. "Institutions do not hire a resume;" instead, they want someone "good," who has "a clear sense of the profession, including its religious roots; a sense of integrity and honesty; and values that hold true over time." Moreover, the individual should be able to explain why he or she would want to spend an entire working career in a library. (When asked if presidents and provosts would look for the same qualities, he responded that "the good ones will.... They want people who are like themselves.")

The director at site $\mathrm{R}$ said that an individual does not need to possess any one set of skills but, rather, that "different successful directors have different skills." At a minimum, it is important to have good communication skills, consensus-building skills, leadership skills, political skills, intuition, and networking skills. Moreover, the director should be 
visionary and recognize the complexity of a university or ARL library and the "pressures that arise from different constituencies." As for personal and personality characteristics, he or she must be empathetic, a decent human being, nurturing, even tempered, and an advocate, and able to synthesize and represent the ideas of others.

For the future, this director did not see a shift to a high-tech person as director but has noticed a trend toward a more humanistic management style and a clear expectation that ARL directors will be effective fund-raisers, internally and externally. Management and leadership skills will remain most important, and he commented that the feminization of the ARL directorship position has been significant.

As several directors mentioned, not everyone in upper administration is meant to be a director. The successful candidate should have knowledge, experience, and a vision ("know the direction that the library is going and not be reactive-articulate these through planning documents and speeches"). In addition, he or she should have good judgment and an appealing personality and be flexible and risk oriented, a problem solver and politically savvy, and able to accept evolutionary change and cope with the pace of change, demonstrating organizational agility.

To this list, the director at site $\mathrm{G}$ added an "understanding of basic business principles and budgets" and the director at site I mentioned knowledge of information technology - "its role and the changes it brings." As the director at site B noted, "Information technology is now integral to the reputation of the institution and the priorities of the provost. Now, the provost travels around the world talking about the library and its visible role with technology. This never happened in the past."

The director at site S emphasized that directors must be "outward looking," adaptable, and "able to go with the flow of whatever is coming down the road in terms of how information is being delivered and what we're doing." The director at site $\mathrm{N}$ explained that:

A big part of being successful in these jobs is being a good administrator and manager of people. That may be different from leadership: I have a hard time separating these two. The administrator role is a sine qua non because you have your constituencies ... and they all put pressure on you, and very often they want different things, and you're this middle person, and you've got to have the trust of all those groups or you can't do the job. There are cases when we can't be honest, when there are personnel issues involved, but if you're honest most of the time and every time you can be, people will understand and accept those times when you don't explain.

Several directors mentioned their desire to shape library programs consistent with library and university strategic plans. The director at site I stressed the belief that he could lead the library and provide the necessary resources and political positions. Finally, library directors, it was noted by the senior management team (pretest interview, site A), have a skill set different from most deans. They are focused externally, but when they focus internally, they "hold us accountable by asking the right questions." They focus on "alignment" by ensuring that their vision matches that of the senior management team; they ask questions but do not micro manage. They offer a vision and openly communicate it, bringing staff to assist in advancing it; and they support innovation. They are much more of a leader than a manager, but they have a "strong management background."

The director at site $C$ listed management as the first priority, followed by a vision of the library - "bringing it into the twenty-first century." To this list, she 


\section{FIGURE 5}

Key Attributes Identified in the Interviews

Broad knowledge and varied experiences (e.g., with technology) as well as the following attributes:

\section{Ability to:}

- appreciate the value of education*

- balance diverse activities simultaneously

- be perceived as an equal of faculty and deans

- be successful with donor relations and grant seeking*

- do budgets (and understand quantification)*

- coach people*

- resolve conflict

- cope with change

- delegate responsibility effectively

- be externally focused:

- communicate with staff (ensure they are externally focused)

- present library to external community

- concentrate on "big picture" and keep library focused on it (where the library is going and how services will change; able to gain support of external audience, such as upper administration and state legislature)

- create work environments that make people productive

- engage in systems thinking and systems analysis

- forge cooperative collection development arrangements, partnerships, consortia*

- keep commitments

- learn

- maintain a balanced view (professionally and personal)

- make tough decisions

- manage human resources effectively

- plan (fiscal management and resource allocation, e.g., collection building [e.g., the place of print collections], partnerships, consortia, preservation, and conservation)

- plan (strategic vision of library and place of technology in higher education and the university)

- relate to the elderly (donor relations)

- respond to pressure from different constituencies

- see library as publisher*

- sense problems when working with staff

- synthesize and represent the ideas of others

- understand complex environment in which library operates

- understand the academic community (e.g., faculty and upper administration) and how academic institutions operate; know how the community views the library

- use different decision-making styles depending on the situation

\section{Skills}

- analytic/problem solving

- business

- budgeting

- communication: oral and written (e.g., with upper administration)

- group process

- interpersonal

- negotiation
- networking

- nurturing

- organizational

- public relations and marketing

- people

- political savvy (e.g., politics of budgeting)

- (reasoned) risk taking

- social (and have social graces)

- team building 


\section{FIGURE 5 (Continued) \\ Key Attributes Identified in the Interviews}

\section{Individual Traits}

- Accessible (to staff and others)

- Adaptable

- Advocacy of issues important to librarianship

- Agility (organizational)

- Appealing personality

- Articulate

- Change focused (know what to change and when to make the change)

- Collaborative

- Comfortable with ambiguity

- Comfortable with numbers

- Commitment to service

- Common decency in dealing with people and empathetic

- Consensus builder

- Deftness

- Diplomat

- Educator (as of upper administration)

- Embraces change

- Enabler and facilitator

- Endurance

- Energetic*

- Entrepreneurial*

- Enthusiastic and commitment (job and profession)

- Even handed

- Even-tempered

- Extravert

- Flexible*

- Good judgment

- Good listener

- Good values/ethics

- Has endurance*

- Honesty

- Integrity

\section{Areas of Knowledge**}

- Digital libraries

- Distance education

- Higher education

- Information delivery systems (print and electronic): Both access and content systems

- Intellectual property rights
- Intelligent

- Intuitive

- Knowing when to act and be quiet; and that he or she cannot do everything

- Leader

- Likes people

- Likes to travel

- Manager

- Mature

- Not try to please everyone all the time

- Objective

- Open minded

- Persuasive

- Relationship building

- Resilient

- Self-awareness (strengths/weaknesses)

- Self-confident (but willing to admit mistakes and not believe he or she has all the answers)

- Sense of humor and perspective

- Sense of profession

- Stamina*

- Think creatively

- "Think on one's feet"- “wing it"

- Think "outside the box"

- Tolerant of ambiguity*

- Tolerant of ceremony

- Tolerant of chaos

- Visibility (on campus)

- Visionary

- Willingness to be held accountable for finances

- Willingness to explain decisions

- Willingness to learn and listen

- Management issues

- Outcomes assessment*

- Publishing (e.g., electronic)*

- Rare books

- Re-engineering

- Scholarly communication*

- Technology*

Notes: *signifies that the attribute was mentioned as having significance for future directors. **See also Figure 4. 
added the perception that "the faculty perceive you as an equal." Figure 5 lists the attributes that the directors interviewed suggested were necessary. The director must have a plan to guide future services, broad experiences, and a command of issues and trends (e.g., information technology, higher education, intellectual property rights, reengineering, management, fund-raising, rare books, and digital libraries) (see also figure 4). He or she is not a day-byday manager but, rather, guides the senior management team to ensure that the library is going in "the right direction" and, as she explained, that "the buck stops here." The directors at sites B, C, and $G$ also noted that they are often asked for a vision of the library and to present the library's mission to different groups.

\section{In addition, the director must be active in fund-raising. If there is a development office and good support staff there, he or she can reduce the amount of time spent in development activities.}

The director at site $\mathrm{Q}$ identified these attributes as being most essential: flexibility, having a vision and being able to communicate it, negotiation skills, good political skills for dealing with campus politics, being a facilitator; having expertise with planning, budgeting, and handling tough personnel issues; and being a good communicator, being good with people, and having excellent public presentation skills. A director must "be able to engage in multiple tasks: being able to do six things at the same time and keeping each one straight." "Many new directors," it was pointed out, "are surprised at the pace of the position; they must cover so many things at the same time."

The same director (site Q) noted that "Good management skills got us to the position, but these are not the skills that will enable us to survive. We need more negotiation skills, an ability to under- stand budgets, and be more willing to delegate." Also important for the near future are the facilitator role and "being able to sell the library program in a tough financial climate. We are one of many parts of the campus competing for resources."

Four directors (sites B, M, P, and Q) stressed the importance of partnerships and consortia. For instance, the director at site $\mathrm{P}$ explained that, in the consortial environment, the digital environment, the fiscal environment, and new opportunities involve the director more and more. He or she must have associated skills that involve the library with other libraries and with other organizations (e.g., art museums to build and support digital activities). The director at site $\mathrm{P}$ saw many potential benefits to his involvement in consortial activities, for example, to share costs and assets; "tap into expertise that the library is not always able to replicate"; "build political ties and strengths"; and be more competitive in seeking outside funding. Involvement in consortia means that the director must build new communities and the staff must create peer relationships. However, there are "many layers in which the director will not have direct control. That person must delegate on a massive scale and realize that some of these layers will be outside his or her control."

This same director (site $\mathrm{P}$ ) added that the entrepreneurial role of the library has expanded and will become even more important in the future. He mentioned that in the year 2003, he has a mandate to generate $\$ 500,000$ in new income. He will do this through business development such as:

- leverage space (rent space for functions);

- leverage traffic (e.g., maintain a coffee lounge in the library);

- participate in cooperative projects that generate income; and

- engage in e-commerce (outside business activities such as electronic book publishing and electronic information services to new markets). 
The director must have good business skills and be willing to take risks. However, the pressure is on that individual "to get it right." Therefore, it is important to generate risk capital, to get funds to experiment: "be successful and approach experimentation as a learning experience" in case something is unsuccessful. He did not speak in terms of failure but, rather, in terms of a learning experience. Still, it is important to balance success with the learning experience and to ensure that the successes outnumber the learning experiences. He discussed resource development, building partnerships, and raising capital. New directors should be knowledgeable about scholarly communication and publishing, ecommerce, and risk capital. They will have to apply that knowledge to competitive ventures. "Libraries are going places where they did not have to compete historically. To survive, we must be aggressive in our strategic planning. We must cash in on the results of resource development."

He spoke about carrying out the entrepreneurial role in a way that does not compromise local services. "We create firewalls to protect these services: we move money back to the library and benefit from the experiences we gain."

All of the directors have invested significant amounts of time in educating provosts about the library and the environment in which it functions. Given the rapid turnover in presidents and provosts at some institutions, and the rapidly changing campus environment, the director must revisit this educational role constantly.

In addition, the director must be active in fund-raising. If there is a development office and good support staff there, he or she can reduce the amount of time spent in development activities. At a minimum, however, the director must be able to close a deal and "land" the financial support. It was suggested (pretest interview, site A) that directors at private institutions engage more in fund-raising than those at public institutions.
The director at site $\mathrm{C}$ viewed the director as engaging in three roles:

- internal manager;

- externally engaged, but on-campus; and

- externally engaged, but off-campus. Significant amounts of time are spent with the first two roles, but the off-campus role increases when the library and the institution are engaged in a capital campaign. Institutions vary as to the amount of time to allocate among the three roles.

According to the director of site G, "I go to meetings for a living." In such environments, her major responsibility is one of "sales." "I sell the institution and the faculty on the library; the library on funders; the staff on change, conversion to the digital environment, and a changing environment. I also sell the profession of librarianship." Because the library competes with other parts of the university for resources, she must sell the library internally: "We are competing with information systems, the institution's need for a wired campus, the Web," and so forth.

According to the director at site E, individual/personal qualities are most important, and knowledge of, and experience with, information technologies, especially if related to libraries, is critical. He identified the following personal and personality characteristics as desirable: sense of humor, willingness to admit mistakes, ability to listen, and ability to build consensus. When asked if he expects any changes in these attributes in the future, he said that they will remain important but that directors will need to articulate, more than ever, the role of the library in an electronic environment. In addition, they will have to be active players in developing that role, have a good grasp of information technologies and management issues, and be able to play a critical role in formulating the institution's approach to distance education.

As for personal characteristics, the director at site $\mathrm{F}$ suggested that the person must have good listening skills; be con- 
cerned about staff morale ("not be the imperial director"); be objective, flexible, and willing to listen to opposing viewpoints; and be willing to talk honestly with trusted advisers.

In the future, directors will need knowledge of electronic publications and the "paradigm shift" that research libraries are going through. They must support distance education, have the entrepreneurial skills to take advantage of targets of opportunity, and be able to respond rapidly to issues confronting the university and the library. Furthermore, as the director at site $\mathrm{H}$ declared, directors will need people management skills, development skills, and the ability to forge cooperative collection development arrangements. He also suspected that knowledge of technology will be less important as technology becomes easier to use. The director at site $\mathrm{J}$ added that future directors must have an appreciation of education and see librarians as educators. Moreover, they must be "nimble," have "greater sensitivity to demographics of faculty and students (the new Web generation), and recognize the new culture of outcomes assessment," as well as guide the organization through outcomes assessment. The director at site $\mathrm{M}$ emphasized the following attributes for the future:

- a greater command of technology so as to be able to fund and manage technology;

- the ability to manage the new generation of librarians who will have nontraditional backgrounds;

- the ability to respond to the new ways of scholarly communication;

- flexibility; and

- the ability to see the library as a publisher.

The director at site $\mathrm{L}$ emphasized that knowledge of technology would remain important, as would the ability to advance a vision and to network with those on campus involved in the use of technology (e.g., for distance education); knowledge of scholarly communication and publishing; stamina, energy, and en- durance; a tolerance for ambiguity; and good political skills. The director at site Koffered the following general summary of many attributes:

The new skills set is really different than it used to be. There are all those things it used to be: you have to know how the library operates, but you have to know how to get work done through people, to create environments that make it productive for people to do their work, so that they like to come to work. That's hard and it takes time. Revolutionary change is not always the most effective change, in the long run. We need people who have enough innate skills to be a successful fund-raiser - that's really important. Someone who is comfortable spending more time outside of the library than in the library, whether it is on campus with deans and faculty, whether it is with administrators, state legislators, or donors, trying to improve service, communications, etc. To some extent, a university librarian needs to be a marketer; needs to have really good innate marketing and promotion sets of skills, or can identify someone with those skills and hire that person. The university librarian also needs to know how to work budgets, think creatively, and be able to coach people. More importantly, one needs to have a lot of comfort with ambiguity and be willing to take risks.

\section{Furthermore,}

The person must have good values and ethics and be consistent in decision making and the way he or she treats people. One must keep commitments, be even-handed, be a quick decision maker, and be willing to explain his or her decision. And, of course, the person must be readily accessible to staff, users, 
and anyone else who thinks he or she needs to see you.

In the future, "we'll look for people who are even more agile, nimble, and flexible. Things are going to continue to be more complex and chaotic; maybe the skills that we need more than we have used in the past are communications and political skills."

\section{Title of the Position}

When asked about the title of the director's position, the director at site $\mathrm{C}$ mentioned that '“dean' tends to signify that the librarians have faculty status and the person sits on the Deans' Council." She regarded dean, director, or university librarian as common. In some instances, the institution might adopt a different title, such as $\mathrm{CIO}$, and increase the responsibilities of the position.

The director at site $\mathrm{L}$ thought that a title is institution specific and that more important than any title was the line of reporting. The director "needs to report to the chief academic officer (provost). That way, the individual is on a par with the deans and is included in all of the fora and discussions in which the deans are involved." In some instances, "the director of libraries reports to the vice president for information technology. I have seen this line of reporting work well under the right organizational structure and personalities. However, this line of reporting tends to reflect an unstable organization, one that is subject to personnel changes." The director at site $\mathrm{O}$ believed that the title is unimportant. "It's the access that one has to decision-making groups that counts. Having the same title as others in the decision-making structure can help. You can, however, sit with other deans at meetings and still not be at the table where the real decisions are made."

\section{Expectations of Presidents, Provosts, and Search Committees}

How the candidates who make the short list present themselves to the search com- mittee, the provost, and the president is important (assuming they spend much time with the latter two individuals). Directors at several sites mentioned that presidents and provosts may not be very involved with the library and may not understand it as well as they should. Moreover, their expectations may be based on their previous experiences as faculty. At the same time, as the directors at sites $\mathrm{F}$ and $\mathrm{H}$ pointed out, presidents and provosts view the library "as a bottomless pit" financially. "They want someone who doesn't make waves" (e.g., likely to make the faculty complain), and "they have faith that libraries are good but increasingly want proof that they make a difference."

The director at site $\mathrm{N}$ has found that:

presidents focus on the fund-raising aspect of the job, and the candidate's potential to be a good fund-raiser might be more important to the president. Provosts, traditionally, are not as involved in fund-raising. Both want us to keep the faculty out of their offices; they want the library out of the newspapers. They want someone who can run the library well and please the faculty. So many provosts go on to become presidents, that their expectations must be about the same.

Another director (site C) found it difficult to generalize about search committees. In some instances, the provost works closely with a committee and prefers to make the final selection. In other instances, the committee makes the decision. In that case, a member's preference may color the outcome. She remembered that she once failed to get a job because she did not get along with one of the committee members. Thus, a single member may wield "a lot of power and influence." In some instances, such as at the University of Notre Dame, the search was turned over to an executive search firm. In that case, a search committee would not see the list of applicants. In 
either situation, the library staff are not powerless. If they objected strenuously to a particular candidate, they could influence the process. After all, the committee would not want to see a bad situation emerge if that person were hired.

As for the role of the provost and the president in the selection of a director, two directors (sites B and C) suggested that the "chemistry" between the candidate and provost/president/chancellor is important. The director works closely with these people, especially when there is frequent turnover in these positions. When told that in another director's experience, the search committee played an important role and the provost deferred to its decision, the director at site B said that such a situation was not common in his experience. In his experience, a committee generally produced an unranked list of acceptable candidates and the provost made the selection. Clearly, a provost looks for different qualities than the library staff do. Several directors mentioned that ARL's executive director and others may be asked to comment on the final slate of candidates for an ARL position.

The director at site B noted that the provost, or even the president, would want someone knowledgeable about, among other things, budgets and technology. The provost and the president also might have short-term goals, such as renovation of the library building, and would expect someone with that knowledge. The director at site $G$ emphasized the institutional expectation of a manager able to deal with a large budget and of an institutional leader. The director at site J noted that presidents and provosts:

expect the director to be a leader and to "put the institution on the map." They want the institution and the library to have a higher profile. They want an outward look, involvement with the larger community. They "want someone who doesn't whine" and who isn't always asking for more money.
They want someone who supports the university's overall mission. They want the director to be a colleague for purposes of governance.... They appreciate the library.

Finally, according to the director at site M, they want someone who (1) can function with minimal attention and direction; (2) can be trusted financially, politically, and socially; and (3) is acceptable to the faculty.

\section{Other Comments}

According to the director at site $\mathrm{K}$,

My perception is that the group of those seeking a directorship is characterized by a lot of mediocrity. That is not to say that there are not terrific people out there. There are, and I would never be so arrogant to think that no one matched or exceeded my, or my good colleagues', talents. But I don't see great minds at work. I see many people who are ambitious for a position without understanding what that position is. I see a lot of people who seem to be more concerned about process than they are about substantive outcome. While I now respect process more than I ever did, process is only a tool. What I worry about more from this group of people is that a lot of the good ones are not interested in taking the step into the directorship. They are perfectly satisfied where they are; they would have to give up their specialties. Some directors will tell them that their lives will be totally consumed by the job. [As a result,] they ... [take] themselves out of that race entirely.

According to this same individual, there are "a lot of good people out there, but perhaps not enough. Some have 'fatal flaws.'" The director at site $\mathrm{H}$ agreed that there are a number of qualified in- 
dividuals but commented that "a high percentage aren't willing to become an ARL director because of the time and demands involved. Many of them are making enough money that the extra salary is not an adequate incentive."

The concern of one director (site B) was that many assistant and associate university librarians lack breadth of knowledge, experience, and skill. In his view, the only way to gain political skills is through experience, which most likely will come from being the director of nonARL libraries. He asked, "Are we producing enough people who can assume ARL directorships?" Furthermore, "People are not being mentored like they were in the past." Those mentoring relationships, at that time, were intended for "king making." ARL, he maintained, is less "the good old boy/girl club today."

The director at site E had a limited basis for advancing an opinion but, nonetheless, considered the pool to be "thin." He suspected that some potential candidates may not apply for the position because they see a directorship as "risky" (they might not be up for the task) and "stressful." Yet, people might be interested in the position for the following reasons: ego, belief that they can make a difference, prestige of the university, spousal accommodation, personal reasons, move to a university with a positive attitude toward the library, desire to leave an unpleasant situation, and preference to move to a better budgetary situation. The director at site $\mathrm{F}$ added "power, prestige, the intrinsic rewards for being a leader (e.g., can make a difference), more independence, and money." The director at site $\mathrm{M}$ also mentioned money but noted that the salary needed to improve "to compete with the private sector." One person (site H) discounted money. He stated that "it's not enough." Rather, he stressed "chance to fulfill a vision, especially as it revolves around staff who deal with the details of the vision. I have a chance to lead a good staff." He also mentioned the opportunity to further the library's cause within the university. Conversely, people may not want the position due to the high demands the directorship places on one's time. It is also "more difficult to have a private and research life," and there can be the pressures of a dual-career family. The director at site $\mathrm{K}$ added: "It is fun and fulfilling. Imagine being able to help an institution move through whatever transformation it is in. Moreover, I love to meet people, to work with people, and to raise money. I would like to have left a strong positive legacy when I retire."

According to one interviewee (site $\mathrm{N}$ ), "It is a very interesting and exciting job, and particularly today with so much change going on; it's constantly challenging." He also mentioned the stimulating environment and the people whom he gets to meet and work with "both here and nationally/internationally." Furthermore, "I do like libraries and their contribution to society." Besides, "I have affected the university in some way. That's heady stuff."

The director at site $\mathrm{M}$ added that other reasons for becoming a director include: nurturing the growing role of librarians on campus, the challenging and stimulating environment, the central role of the library on many campuses; and the opportunity to be part of the university's senior management team.

A director must have "credibility" with upper administration and the faculty. One director (site B) cited as an example the problem with the new online public access catalog (OPAC) not functioning as expected. "If I did not have a lot of credibility with upper administration, they might have called for my resignation. Fortunately, the administration believes in me." In closing, the director mentioned that a position such as his is becoming "intimidating" and "high risk"; some of his peers are being forced out or are losing their influence. Clearly, the director must have "a sense of how long to stay," and he foresees some early retirements. He mentioned that William Studer was director at Ohio State University for more than a quarter of a cen- 
tury. "I do not see others staying in the position as long." Nonetheless, he finds the position "most satisfying"; he "enjoys fund-raising, explaining what the library does, being externally focused, and working long hours."

The director at site D noted the changing role of the university librarian. He explained that he was hired as a collections officer but spends little time in that activity. He added that one of the benefits of the job is that "you work with world-class collections." He spends more time on staff issues (i.e., hiring and retaining good people, and staff development) and program matters (e.g., instruction). Another job benefit, he explained, is "the people I work with....I expect first-rate performance from my staff" and find that the library affords an environment of challenge "to my staff and myself....The work environment should be as demanding and challenging as possible." As he explained, "The people whom we hire want to be challenged by their colleagues. What is worse than a dull colleague? I work with great people." He also issued a challenge: 1ibrary schools should foster a challenging environment, show that it presents exciting and unforeseen opportunities, and expect intellectual rigor from their faculty and students. "We cannot always know what to expect."

\section{Topics Meriting Further Investigation}

Peter R. Scholtes, an internationally known consultant, views leaders as needing to engage in systems thinking (viewing the organization in its entirety and ensuring that each part realizes that, by itself, it cannot achieve the systems' mission and that each part depends on the other parts); to understand people and why they behave as they do, the variability of work, how people learn and develop, and interactions among systems, variability, learning, and human behavior; and to give "visions, meaning, direction, and focus to the organization." ${ }^{29} \mathrm{He}$ described forty-six "habits of pretty good leaders," such as the need to understand motivation, to be a good listener and a good questioner, and to engage in honest, clear communication. ${ }^{30}$ In the context of being a planner, a leader must engage in systems thinking and analysis and must possess certain skills (e.g., community skills). ${ }^{31}$ These so-called habits do not focus exclusively on attributes, whereas figure 5 identifies more than a hundred attributes pertinent to the leadership position in ARL libraries. Nonetheless, those forty-six habits, as well as other attributes of CEOs and college and university presidents and others in upper administration positions, merit investigation and comparison with the findings of this study. ${ }^{32}$ After all, university directors could move to other administrative positions within universities.

The director at interview site $C$ suggested the need for a study that examines the career path that current directors have taken: what positions have they held and in what geographical regions. The director at site D suggested an examination of recently hired directors, perhaps through the use of case studies on the perceptions of some of these individuals, together with members of the search committee and the president and the provost at selected institutions.

Most of those interviewed also recommended that research examine individuals in associate/assistant/deputy librarian positions to determine why they might (or might not) be interested in the directorship. How well prepared are those individuals wanting to move into directorships and those who are hired? Some of those interviewed believed that directors do not jump from position to position but, instead, tend to settle at one place for a long time-perhaps a decade. How long, in fact, do directors stay in one position? The director at site E asked, "Why don't more directors of prestigious liberal arts college libraries seem to be interested in the position?"

It might be productive to examine the extent to which potential candidates for the directorship have acquired the attributes regarded as most essential (to be 
identified in part two). How well do education and training programs address these attributes? In addition, research might examine the adequacy of the coverage of the key attributes through mentoring and succession planning. Furthermore, Morgan W. McCall Jr., in High Flyers, defined development, in part, as "the acquisition of abilities - bringing new things into being; aspirants for the top position in a firm should be able to learn from their experiences, acquire new skills that are adaptable to new situations, and be receptive to continuous learning. ${ }^{33}$ Through case study research, it might be advantageous to examine how McCall's view of development applies to individuals in associate/assistant/deputy director positions. Finally, there might be a closer examination of educational degrees obtained. For instance, how many have a master's degree in business administration? Are the institutions at the upper echelons of ARL more likely to require or prefer a doctorate?

\section{Study Limitations}

This article did not examine the directorship from the perspective of the faculty, upper administration, and search committee for directors, nor did it use a case study design to ascertain why individuals are selected as directors. Moreover, it did not reflect the perspectives of everyone in upper library administration at the interview sites, nor did it represent the perspective of all ARL directors. Further, it did not examine how well directors balance their internal and external roles. For instance, do faculty and library staff view the internal role as being slighted? How well do they think the directors have mastered the attributes identified in this study? Finally, why have individuals left the directorships? Was the decision voluntary or imposed? These important questions are outside the scope of this study.

\section{Conclusion}

In reading a draft of this paper, ARL staff pointed out the relevance of the ARL annual agenda or program plan. They noted that library directors/leaders shape the program priorities and that ARL provides a forum for them to meet and define common ground for operating within that agenda. Committee chairs and members formulate a vision that is translated into a course of action, one having annual operating and developmental priorities. The operating priorities for 2000 were to "provide leadership in advocacy and educational efforts within the research and educational community in the areas of information and telecommunications policy, copyright, and intellectual property; ...create and implement cost-effective strategies for managing scholarly communication in partnership with other organizations;... help research libraries and their constituencies to develop new approaches and models for measuring and improving their service effectiveness, diversity, and leadership;" and "advance the development, preservation, and accessibility of research collections through local institutional efforts, collaborative library efforts, and the application of networking technologies." 34

Mentioned among the developmental priorities is a goal related to the topic of this paper, namely to "develop effective strategies to assist member libraries in recruiting talented staff in a changing demographic environment."

Central to this effort will be defining the core competencies for research library staff and identifying the means by which staff can acquire these skills. ARL must also help to develop a pool of library leaders who can motivate and direct efforts to adopt new service roles and to ensure broad, enduring access to research resources. ${ }^{35}$

Clearly, knowledge of the attributes identified and refined in this two-phase study will be useful to ARL in meeting its developmental priorities.

Obviously, the personal experiences of the directors interviewed shaped their 
answers regarding career paths to the position. Nonetheless, the key requirement appears to be a local environment that is nurturing and offers guidance and opportunities to grow and gain new and varied experiences. At the same time, those interested in becoming directors in the future should attend ARL-sponsored programs and gain recognition for their competency and dedication. Leadership institutes also offer nurturing environments and further recognition; they might provide a step toward a directorship.

The director is now externally focused. He or she is active on and beyond campus, interacting broadly with the university community, donors, and stakeholders on a wide variety of issues. He or she also is visionary and articulate, representing the library and the university. Clearly, this individual must be a manager and a leader, but not someone deeply involved in the day-to-day operations of the library and isolated or spending much of his or her time internally in the library.

A number of directors spoke about the match between the institution and the individual to ensure that the right person is hired. Individual institutions and circumstances of the moment may dictate which attributes are most important.

The number of attributes identified is quite extensive. The purpose of the second phase of the study will be to use the Delphi technique to identify which ones are most important. Furthermore, in that phase it will be possible to link the results of figure 5 with these results, knowing that certain institutions may still find some attributes more important than others. McAnally and Downs identified the following "qualities of a model director": flexibility, adaptability, accepting "change as a way of life," "open-minded about alternatives," possessing "a stable and equable temperament and the ability to keep his emotional balance under constant tensions that come at him from all directions." Furthermore, the director "must have endurance," "be exceptionally persuasive," have "a personality that commands attention and respect," and "be a leader and not merely an authority." ${ }^{36}$ Given the time they wrote their paper, it is not surprising that they were referring to a male director. Nonetheless, their list of qualities remains relevant, but, to be expected, other key qualities have emerged.

With a shortage of librarians predicted within the next decade, key questions become: Where will future generations of ARL directors come from? and How well prepared will they be to assume the position of leadership? ${ }^{37}$ We all have a stake in the answers to these questions. It is critical, therefore, that the profession look more closely at the emerging list of attributes and await their schematic representation and refinement through the second part of the study.

\section{Notes}

1. See, for example, Arthur M. McAnally and Robert B. Downs, “The Changing Role of Directors of University Libraries," College E Research Libraries 34 (Mar. 1973): 103-25; Marcia J. Myers and Paula T. Kaufman, "ARL Directors: Two Decades of Change," College $\mathcal{E}$ Research Libraries 52 (May 1991): 241-54; William L. Cohen, "An Overview of ARL Directors, 1933-1973," College $\mathcal{E}$ Research Libraries 37 (Mar. 1976): 137-44; Jerry Parsons, "How Have They Changed? Characteristics of Research Library Directors, 1958 and 1973," Wilson Library Bulletin 50 (Apr. 1976): 613-17; Paul Metz, "Administrative Succession in the Academic Library," College E Research Libraries 39 (1978): 358-64; Barbara Moran, "Career Patterns of Academic Library Administrators," College E Research Libraries 44 (1983): 334-44; Louis Kaplan, "Letter to the Editor: Directors of University Libraries," College $\mathcal{E}$ Research Libraries 38 (Nov. 1997): 521; Ronald Dale Karr, "The Changing Profile of University Library Directors, 1966-1981," College E Research Libraries 45 (July 1984): 282-86; Moran, "Getting Ahead in Academic Library Administration," Library Personnel News 3, no. 4 (fall 1989): 54-55; Stanley J. Wilder, The Age Demographics of Academic Librarians: A Profession Apart (Washington, D.C.: ARL, 1995); - - -, "The Age Demographics of Academic Librarians: A Profession Apart," Journal of Library Administration 28, 
no. 3 (1999): 1-84.

2. Wilder, "The Age Demographics of Academic Librarians," 41.

3. Frank D'Andraia, ed., The Academic Library Director: Reflections on a Position in Transition (New York: Haworth Pr., 1997).

4. Rebecca R. Martin, "Recruiting a Library Leader for the $21^{\text {st }}$ Century," in The Academic Library Director, 50.

5. McAnally and Downs, "The Changing Role of Directors of University Libraries," 103.

6. Stanley Wilder, "The Changing Profile of Research Library Professional Staff," ARL Newsletter 208/209 (Feb./Apr. 2000): 1-12.

7. In the case of nonacademic ARL libraries and Canadian ARL libraries, there is some variation. Directors have come from non-ARL public libraries, the National Research Council, or an administrative position in university advancement at one university. A controversial appointment centered on the elevation of a novelist to the directorship.

8. This information, together with the data for figure 2, was supplied by ARL (Aug. 2000).

9. Terrence F. Mech, "Academic Library Directors: A Managerial Role Profile," College $\mathcal{E}$ Research Libraries 51 (Sept. 1990): 415-28.

10. Michael Ann Moskowitz, “The Managerial Roles of Academic Library Directors: The Mintzberg Model," College E Research Libraries 47 (Sept. 1986): 452-59.

11. Mech, "Academic Library Directors," 426.

12. Keith M. Cottam, "Directors of Large Libraries: Roles, Functions, and Activities," Library Trends 43 (summer 1994): 15.

13. Susan K. Martin, "The Changing Role of the Library Director: Fund-raising and the Academic Library," Journal of Academic Librarianship 24 (Jan. 1998): 3.

14. Dana C. Rooks, "Terms for Academic Library Directors," Library Trends 43 (summer 1994): 60,61 .

15. Ibid. McAnally and Downs found the same three qualities as important. See McAnally and Downs, "The Changing Role of Directors of University Libraries," 122.

16. Peter Hernon and Carolynne Presser in an internal review of a library system (1997). The characteristics were published as part of Hernon, "Editorial: The Library Director as ScholarLibrarian," Journal of Academic Librarianship 24 (Mar. 1998): 111-12.

17. Mech, "Introduction," in Leadership and Academic Librarians, ed. Terrence F. Mech and Gerald B. McCabe (Westport, Conn.: Greenwood, 1998), x.

18. Richard T. Sweeney, "Leadership in the Post-Hierarchical Library," Library Trends 43 (summer 1994): 62-94.

19. Ruth J. Person and George C. Newman, "Selection of the University Librarian," College $\mathcal{E}$ Research Libraries 51 (July 1990): 346-59.

20. Ronald R. Powell and Nancy Becker Johnson, "Education for Research Librarianship: A Preliminary Assessment of the Michigan Program," Journal of Education for Library and Information Science 27 (winter 1987): 169-84; Ronald R. Powell and Sheila D. Creth, "Knowledge Bases and Library Education," College E Research Libraries 47 (Jan. 1986): 16-27; Ronald R. Powell, "Sources of Professional Knowledge for Academic Librarians," College E Research Libraries 49 (July 1988): 332-40.

21. One of these interviews was conducted in person at the site and focused on the final set of questions that guided the study. Thus, the authors included the findings as site A.

22. For example, see "Dean of Libraries: The University of Tennessee, Knoxville," American Libraries 30, no. 11 (Dec. 1999): 102.

23. "Dean and Director of Libraries," College E Research Libraries News 61 (Jan. 2000): 77.

24. “Dean, University Library System," American Libraries 31, no. 1 (Jan. 2000): 112.

25. This characterization is not meant to reinforce the stereotypical image of a single or childless female librarian. It was offered by both a male and a female director to show the time commitments and pressures of the position.

26. The director at site I believed that, for now, directorships will be filled by administrators within ARL libraries. The future, he thought, might see the pool expanded, as more administrators demonstrate knowledge of, and competency with, technology.

27. ARL/OCLC Strategic Issues Forum for Academic Library Directors, "Discussion Paper on Key Issues Facing Academic Libraries" (unpublished) (Washington, D.C.: ARL, 1999), 9.

28. For a summary of his views, see James M. Matarazzo, "Library Human Resources: The Y2K Plus 10 Challenge," Journal of Academic Librarianship 26 (July 2000): 223-24.

29. Peter R. Scholtes, The Leader's Handbook (New York: McGraw-Hill, 1998), 391.

30. Ibid., 391-396.

31. Ibid., 211.

32. Examples of related research for a comparison of attributes include: Stanley D. Truskie, The President/CEO Study: Leadership Behaviors, Skills, and Attributes of Executives Who Lead Cor- 
porate 1000 Companies (Pittsburgh, Pa.: Management Science \& Development, 1990); Kenneth A. Shaw, The Successful President: "Buzzwords" on Leadership (Phoenix, Ariz.: Oryx, 1999); Roni Kelso Bumpas, "Factors That Affect the Selection of Community College Presidents" (Ed.D. diss., Texas A\&M University-Commerce, 1998); Stephen D. Regan, "Becoming a Dean: The Impact of Humanistic Counselor Training on a Career in Academic Administration," Journal of Humanistic Education and Development 37 (Sept. 1998): 21-26 ; James A. Hood, "An Analysis of Selection Criteria, Roles, Skills, Challenges, and Strategies of Two-year College Presidents" (Ph.D. diss., Univ. of Alabama, 1997); Robert Hahn, "Getting Serious about Presidential Leadership: Our Collective Responsibility," Change 27 (Sept./Oct. 1995): 12-19; Eleanor Fujita, "A Good College President: The Constituent View," Journal of Personnel Evaluation in Education 8 (Feb. 1994): 75-91. See also the $21^{\text {st }}$ Century Education Leader Project, which was developed by the Institute of Higher Education at the University of Florida in cooperation with Saville and Holdsworth, Ltd. Available online at http://www.coe.ufl.edu/Leadership/Distance/leaders/ dev\&sel.html (accessed 15 August 2000). This site, for example, lists "essential," "important," and "relevant" attributes for twenty-first century educational leaders.

33. Morgan W. McCall Jr., High Flyers: Developing the Next Generation of Leaders (Boston: Harvard Business School Pr., 1998), 5, 11.

34. ARL Activities Report 2000 (Washington, D.C.: ARL, 2000), 2. Available online at http:// www.arl.org/arl/activities/ (accessed 16 October 2000).

35. Ibid., 3. 23.

36. McAnally and Downs, "The Changing Role of Directors of University Libraries," 122-

37. Matarazzo, "Library Human Resources." 


\section{Library Technologies (Repeat Jan. 01, pg. 2) P.146}

